\title{
The effect of dietary protein intake on calcium metabolism of the pregnant ewe
}

\author{
BY G. D. BRAITHWAITE \\ National Institute for Research in Dairying, Shinfield, Reading RG2 $9 A T$
}

(Received 13 January 1978 - Accepted 10 April 1978)

\begin{abstract}
I. The effect of protein intake on calcium metabolism has been studied in the pregnant ewe.
2. Results suggest that decreased $\mathrm{Ca}$ retention in protein-deficient animals was a result of a decreased rate of $\mathrm{Ca}$ absorption and not a decreased rate of bone accretion as suggested by other workers.
\end{abstract}

The considerable losses in skeletal calcium content of hill sheep that frequently occur during pregnancy (Field, Suttle \& Gunn, 1968) are probably a result of an inadequate protein intake rather than an inadequate $\mathrm{Ca}$ intake (Sykes \& Field, 1972). Sykes \& Field (1972) suggested that the deficiency of dietary protein may have resulted in impaired formation of bone matrix with a consequent decrease in the rate of accretion of $\mathrm{Ca}$ into bone and hence a decreased $\mathrm{Ca}$ retention.

$\mathrm{Ca}$ kinetic studies with pregnant ewes now show that this decrease in Ca retention occurs as a result of a decreased rate of $\mathrm{Ca}$ absorption and that the rate of bone accretion remains unchanged.

\section{EXPERIMENTAL}

Eight 4-year-old Suffolk $\times$ Clun Forest ewes weighing $60-65 \mathrm{~kg}$ were used. At I month after mating they were placed in individual metabolism cages designed for the separate collection of urine and faeces and were randomly divided into two equal groups. One group was given a protein-deficient diet and the other a diet adequate in protein (Agricultural Research Council, I965). The composition of the diets is shown in Table I. Uneaten food was collected daily and the total amount eaten determined.

$\mathrm{Ca}$ kinetic studies were done at $\mathrm{I} 35^{-140} \mathrm{~d}$ gestation and the various processes of $\mathrm{Ca}$ metabolism calculated by the method of Aubert \& Milhaud (I960) modified for use with sheep (Braithwaite, Glascock \& Riazuddin, 1969; Braithwaite \& Riazuddin, 197I; Braithwaite \& Glascock, 1976). The methods used for the determination of $\mathrm{Ca}$ and radioactivity in samples of blood, urine, faeces, food and foetal tissues have been described previously (Braithwaite et al. 1969).

\section{RESULTS AND DISCUSSION}

The results of these studies are summarized in Table 2. Considerable losses of body-weight $(15-17 \%$ ) occurred during pregnancy in both groups of ewes but no significant effect attributable to the reduced protein intake was observed. In previous studies with a large number of ewes, however, Sykes \& Field (1972) did find a slight but significant increase in body-weight loss in protein-deficient animals.

Neither group of ewes absorbed enough dietary $\mathrm{Ca}$ to meet the high demands of late pregnancy and retention was negative. This is not unexpected, however, as it has previously been shown that an unavoidable negative retention occurs in late pregnancy irrespective of the dietary supply of Ca (Braithwaite, Glascock \& Riazuddin, 1969, 1970). Although the rates of $\mathrm{Ca}$ ingestion and $\mathrm{Ca}$ loss into urine, intestine and foetuses were approximately 
Table I. Daily intake (/kg body-weight) of dietary ingredients by control and protein-deficient ewes

\begin{tabular}{|c|c|c|c|c|c|c|c|c|}
\hline \multirow[b]{2}{*}{ Ingredient } & \multicolumn{2}{|c|}{ Intake (g) } & \multicolumn{2}{|c|}{$\begin{array}{l}\text { Total calcium } \\
\text { (mg) }\end{array}$} & \multicolumn{2}{|c|}{$\begin{array}{l}\text { Total phosphorus } \\
\text { (mg) }\end{array}$} & \multicolumn{2}{|c|}{$\begin{array}{l}\text { Total protein } \\
\text { (mg) }\end{array}$} \\
\hline & Control & $\begin{array}{l}\text { Protein- } \\
\text { deficient }\end{array}$ & Control & $\begin{array}{l}\text { Protein- } \\
\text { deficient }\end{array}$ & Control & $\begin{array}{l}\text { Protein- } \\
\text { deficient }\end{array}$ & Control & $\begin{array}{l}\text { Protein- } \\
\text { deficient }\end{array}$ \\
\hline & 8 & 8 & $30 \cdot 8$ & $30 \cdot 8$ & 3.7 & $3 \cdot 7$ & $364: 3$ & $364 \cdot 3$ \\
\hline & 6 & 6 & $3 \cdot 2$ & $3 \cdot 2$ & $20 \cdot 3$ & $20 \cdot 3$ & 333.8 & 333.8 \\
\hline ein & 0.7 & - & I. 3 & - & $1 \cdot 0$ & - & 501.9 & - \\
\hline eral mixture* & 0.4 & 0.4 & $59 \cdot 2$ & $59 \cdot 2$ & $46 \cdot 3$ & $46 \cdot 3$ & - & $\ldots$ \\
\hline Total & - & - & $94 \cdot 5$ & $93 \cdot 2$ & $71 \cdot 3$ & $70 \cdot 3$ & $1200 \cdot 0$ & $698 \cdot I$ \\
\hline
\end{tabular}

* Super Mindif (Boots Pure Drug Co., Nottingham). Diets also contained Beta vitamin no. 3a (Cooper Nutrition Products Ltd, Witham, Essex) to supply (/kg body-wt) $37.5 \mu \mathrm{g}$ cholecalciferol.

Table 2. A comparison of the calcium metabolism in late pregnancy of control and proteindeficient ewes which had received respectively an adequate and a deficient protein intake $\dagger$ throughout pregnancy

(Mean values with their standard errors for four animals/group; tests of statistical significance determined using the $t$ test)

\begin{tabular}{|c|c|c|c|c|c|}
\hline & & & Protein- & ficient & $\begin{array}{c}\text { Statistical } \\
\text { significance }\end{array}$ \\
\hline & Mean & $\mathrm{SE}$ & Mean & SE & between means \\
\hline Rate of ingestion of $\mathrm{Ca}(\mathrm{mg} / \mathrm{d}$ per kg body-wt) & $90 \cdot 5$ & 0.7 & $90 \cdot 0$ & 0.9 & NS \\
\hline Rate of loss of $\mathrm{Ca}$ in faeces $(\mathrm{mg} / \mathrm{d}$ per $\mathrm{kg}$ body-wt) & 80.3 & $2 \cdot 4$ & $93 \cdot 1$ & $1 \cdot 3$ & ** \\
\hline Rate of excretion of $\mathrm{Ca}$ in urine $(\mathrm{mg} / \mathrm{d}$ per $\mathrm{kg}$ & & & & & \\
\hline $\begin{array}{l}\text { body-wt) } \\
\text { Rate of transfer of } \mathrm{Ca} \text { to foetus }(\mathrm{mg} / \mathrm{d} \text { per } \mathrm{kg}\end{array}$ & $3 \cdot 2$ & $\mathrm{I} \cdot 3$ & $2 \cdot 0$ & $0 \cdot I$ & NS \\
\hline body-wt) & $17 \cdot 3$ & 3.4 & $20 \cdot \mathrm{I}$ & $1 \cdot 0$ & NS \\
\hline Rate of retention of $\mathrm{Ca}(\mathrm{mg} / \mathrm{d}$ per $\mathrm{kg}$ body-wt) & $-10 \cdot 3$ & $3 \cdot 8$ & $-25 \cdot 2$ & I. 6 & *** \\
\hline $\begin{array}{l}\text { Rate of secretion of } \mathrm{Ca} \text { intor intestine }(\mathrm{faecal} \\
\text { endogenous Ca) } \mathrm{mg} / \mathrm{d} \text { per } \mathrm{kg} \text { body } \mathrm{wt}) \\
\text { Rate of absorption of } \mathrm{Ca} \text { from intestine }(\mathrm{mg} / \mathrm{d} \text { per }\end{array}$ & II 3 & 0.4 & $11 \cdot 3$ & 0.9 & NS \\
\hline $\mathrm{kg}$ body-wt) & $21 \cdot 5$ & $\mathrm{I} \cdot 3$ & $8 \cdot 3$ & 0.5 & *** \\
\hline $\mathrm{Ca}$ absorbed ( $\% \mathrm{Ca}$ ingested) & 23.8 & $\mathrm{I} \cdot 7$ & $9 \cdot 2$ & 0.5 & *** \\
\hline $\begin{array}{l}\text { Rapidly exchangeable pool of } \mathrm{Ca}(\mathrm{mg} / \mathrm{kg} \text { body-wt) } \\
\text { Slowly exchangeable pool of } \mathrm{Ca} \text { in bone }(\mathrm{mg} / \mathrm{kg}\end{array}$ & $40 \cdot 5$ & $1 \cdot 5$ & $45 \cdot 0$ & $1 \cdot 2$ & NS \\
\hline $\begin{array}{l}\text { body-wt) } \\
\text { Rate of accretion of } \mathrm{Ca} \text { into bone }(\mathrm{mg} / \mathrm{d} \text { per } \mathrm{kg}\end{array}$ & $39 \cdot 0$ & $2 \cdot I$ & $41 \cdot 5$ & $2 \cdot \mathbf{I}$ & NS \\
\hline $\begin{array}{l}\text { bady-wt) } \\
\text { Rate of resorption of } \mathrm{Ca} \text { from bone }(\mathrm{mg} / \mathrm{d} \text { per } \mathrm{kg}\end{array}$ & I3. I & 0.8 & $14 \cdot 5$ & $I \cdot O$ & NS \\
\hline $\begin{array}{l}\text { body-wt) } \\
\text { Loss in body-wt of ewes during pregnancy }\end{array}$ & 23.4 & $3 \cdot 7$ & $39 \cdot 7$ & $2 \cdot 5$ & $* *$ \\
\hline$(\%$ initial wt) & $14 \cdot 8$ & $1 \cdot 9$ & 16.9 & $2 \cdot 2$ & NS \\
\hline
\end{tabular}

the same in each group, the rate of absorption of $\mathrm{Ca}$ was considerably lower in the ewes given the protein-deficient diet. As a consequence, the rate of $\mathrm{Ca}$ retention was lower in these ewes and they had to mobilize greater amounts of their skeletal stores of $\mathrm{Ca}$ in order to meet demands. This was achieved by an increase in the rate of bone resorption relative to that of bone accretion which remained unchanged. 
Although the present measurements refer only to changes in late pregnancy whereas those of Sykes \& Field (1972) are the sum total of changes throughout the whole of pregnancy, this study does appear to show that the decreased retention of $\mathrm{Ca}$ associated with protein-deficient diets occurs as a result of a decreased rate of $\mathrm{Ca}$ absorption and not, as suggested by Sykes \& Field (1972), a decreased rate of bone accretion. Furthermore, this study suggests that losses of bone ash and bone matrix previously observed in proteindeficient pregnant ewes (Sykes, Nesbit \& Field, 1973) are due to an increased rate of bone resorption. Certainly, similar changes in bone structure do occur as a result of increased bone resorption in Ca-deficient rats (Harrison \& Fraser, 1960).

The reason for the decreased rate of $\mathrm{Ca}$ absorption, which has also been observed in protein-deficient rats (LeRoith \& Pimstone, 1973) is at present uncertain. It might, however, be explained by the recent observation that the concentration of intestinal Ca-binding protein, thought to be essential for the vitamin $\mathrm{D}$ mediated active absorption of $\mathrm{Ca}$, is reduced during protein deficiency (Kalk \& Pimstone, 1974).

The author thanks Mrs A. F. A. Jones, Miss S. C. Neville and Mr R. J. Ranson for skilled technical assistance and $\mathrm{Mr} \mathrm{A}$. Mowlem for supervising the care of the experimental animals.

\section{REFERENCES}

Agricultural Research Council (1965). The Nutrient Requirements of Farm Livestock, no. 2, Ruminants. London: HM Stationery Office.

Aubert, J.-P. \& Milhaud, G. (1960). Biochim. biophys, Acta 39, 122.

Braithwaite, G. D. \& Glascock, R. F. (1976). Bienn. Rev. natn. Inst. Res. Dairy. p. 43.

Braithwaite, G. D., Glascock, R. F. \& Riazuddin, Sh. (I 969). Br. J. Nutr. 23, 827.

Braithwaite, G. D., Glascock, R. F. \& Riazuddin, Sh. (1970). Br. J. Nutr. 24, 66r.

Braithwaite, G. D. \& Riazuddin, Sh. (197I). Br. J. Nutr. 26, 215.

Field, A. C., Suttle, N. F. \& Gunn, R. G. (1968). J. agric. Sci., Camb. 71, 303.

Harrison, M. \& Fraser, R. (1960). J. Endocr. 21, 197.

Kalk, W. J. \& Pimstone, B. L. (I974). Br.J. Nutr. 32, 569.

LeRoith, D. \& Pimstone, B. L. (1973). Clin. Sci. 44, 305.

Sykes, A. R. \& Field, A C. (I972). J. agric. Sci., Camb. 78, 109.

Sykes, A. R., Nesbet, D. I. \& Field, A. C. (1973). J. agric. Sci., Camb. 81, 433. 